\title{
RISĀLAH MENURUT KONSEPSI ALQURAN
}

\author{
Mukhlis Mukhtar \\ STAI DDI Maros, Jl. Baniaga Kabupaten Maros, Sulawesi Selatan \\ E-mail: muhlismuhtar82@yahoo.id
}

\begin{abstract}
Abstrak: Kata risālah merupakan salah satu kosakata yang digunakan dalam Alquran. Eksistensi risālah tidak dapat dipisahkan dengan kehadiran para rasul Allah di tengah-tengah umat manusia pada setiap zaman. Para rasul itulah yang diberi rekomendasi langsung dari Allah untuk membawa, menyampaikan dan mengajarkan risālah. Risālah yang dibawa, disampaikan dan diajarkan para rasul kepada umat manusia berisi pesan-pesan Allah swt. untuk mengajak manusia agar tidak menyembah selain Allah serta mengatur kehidupan manusia dalam hubungannya dengan Allah, sesama manusia dan lingkungannya.
\end{abstract}

Abstract: The word al-risalah is one of the words used in the Qur'an. The existence of al-risālah cannot be separated from the presence of the messenger of Allah among mankind in every age. That is because the messengers were given the recommendation directly by God to carry, to deliver and to teach al-risālah. Alrisālah carried, delivered and taught by the messengers to mankind contains the messages of the Almighty God to invite people not to worship God except Allah and regulate human life in relation to God, fellow humans and their environment.

Kata Kunci: risalah, kosepsi Alquran, rasul

\section{PENDAHULUAN}

Dari sekian banyak makhluk ciptaan Tuhan, manusia adalah makhluk utama dan pilihan; pertama, karena misi atau beban yang harus diemban; dan kedua, karena dilebihkan oleh Tuhan dengan kemampuan dan keampuhan akal pikiran. 
Manusia hendaknya memahami, untuk apa ia diciptakan, tugas apa yang harus dilakukan, bekal apa yang harus dibawa, dalam batas mana ia memiliki wewenang dan tanggung jawab dan pada asas mana ia memiliki pedoman sehingga mengetahui arah dan tujuannya. Tanpa demikian, ia akan kehilangan kompas sebagai pedoman, ke mana arah harus melangkah, ke mana tujuan harus berjalan, kapan sampai dan harus berhenti.

Berlandaskan pada pemahaman tersebut, ada sejumlah orang mampu mengetahui yang baik dan yang buruk melalui akal dan suara hatinya. Kelompok ini melakukan perenunganperenungan untuk mencari dan mengenal yang dicarinya, yakni Tuhan. Dengan hatinya memungkinkan mereka dapat selamat dari penyimpangan dan kesesatan. Sebagian lagi mungkin dapat mengetahui yang gaib dan kehidupan lain di balik kehidupan nyata (metafisika) menerima balasan atas perbuatannya di dunia. Begitu pula orang jahat menerima hukuman atas dosa-dosa yang dilakukan di dunia. ${ }^{1}$

Kelompok yang demikian itu (kaum khawās) sangatlah terbatas, sedangkan kaum awam jumlahnya sangat besar. Karena terbatasnya jumlah orang yang dapat mengetahui yang baik dan yang buruk secara meyakinkan dengan menggunakan akal tanpa ada petunjuk, sebagian manusia (kaum awam) membutuhkan sesuatu yang dapat menjadi pegangan dan menguatkan hatinya untuk memastikan yang baik dan yang buruk, yang boleh dan yang tidak boleh dilakukan, yang halal dan yang haram dan seterusnya. Keterbatasan manusia pada umumnya itu, sehingga Allah memilih dan mengutus manusia untuk menyampaikan pesan-pesan agama (risalah). Manusia yang dipilih dan diutus oleh Allah untuk tugas tersebut disebut nabi dan rasul. ${ }^{2}$

\footnotetext{
${ }^{1}$ Yūsuf Mūsā, Islam: Suatu Kajian Komprehensif, terj. Malik Madaniy dan Hamim (Cet. I; Jakarta: Rajawali, 1988), h. 97.

${ }^{2}$ M. Quraish Shihab, Wawasan al-Qur'an: Tafsir Maudhu'i atas Pelbagai Persoalan Umat (Cet. II; Bandung: Mizan, 1996), h. 41.
} 
Para ulama sepakat bahwa manusia membutuhkan rasul yang menyampaikan risālah Tuhan yang berfungsi untuk menunjuki manusia ke jalan yang benar dan menjauhkan manusia dari kesesatan. Meskipun demikian, ulama berbeda pendapat tentang "kewajiban" Tuhan untuk mengutus rasul-Nya.

Para teolog berbeda pandangan dalam masalah ini. Mu'tazilah berpandangan bahwa Tuhan itu Maha Adil. Dengan keadilan-Nya Tuhan wajib melakukan yang baik dan yang terbaik untuk manusia. Tuhan wajib membawa manusia kepada ketaatan dan yang akan menjauhkan manusia dari maksiat. Dengan demikian, Tuhan berkewajiban mengutus nabi dan rasul-Nya untuk membawa petunjuk bagi manusia. ${ }^{3}$

Kaum Asy'ariah memberikan interpretasi yang berbeda dengan kaum Mu'tazilah. Kaum Asy'ariah berpandangan bahwa Tuhan tidak berkewajiban mengutus nabi atau rasul, tetapi hal itu hanya jāiz bagi Tuhan. Pandangan ini didasarkan pada paradigma bahwa Tuhan mempunyai kekuasaan dan kehendak secara mutlak. Tuhan berbuat bukan atas dasar kewajiban dan keterpaksaan, melainkan Tuhan berbuat apa saja yang dikehendaki-Nya. ${ }^{4}$

Kaum Maturidiah mencoba mensintesiskan kedua pendapat yang bertolak belakang itu, namun mereka tidak berhasil. Bahkan mereka sendiri terpecah menjadi dua kelompok, yaitu: kelompok Maturidiah Samarkand dan kelompok Maturidiah Bukharah. ${ }^{5}$

Terlepas dari pandangan wajib atau tidaknya Tuhan mengutus rasul-Nya, yang pasti manusia membutuhkan rasul untuk mengajarkan hal-hal yang gaib, yang wajib diimani, dan batas antara baik dan buruk. Tanpa adanya rasul maka sulit bagi

${ }^{3}$ Harun Nasution, Teologi Islam: Aliran-aliran Sejarah, Analisa Perbandingan (Cet. II; Jakarta: UI Press, t.th), h. 54.

${ }^{4}$ ibid., h. 131-132.

${ }^{5}$ Maturidiah Samarkand condong ke Mu'tazilah sedangkan Maturidiah Bukharah condong ke Asy'ariah. Untuk lebih jelasnya lihat ibid., h. 112-117. 
manusia mengetahui yang gaib, yang baik dan yang buruk. Atas dasar itu maka Tuhan mengutus para rasul untuk membawa risālah. Risālah yang dibawa oleh para rasul mengandung dua hal pokok, yaitu akidah dan syari'ah. Dua hal pokok ini kemudian dijabarkan oleh rasul kepada umat manusia.

Adanya sejumlah wacana dan pandangan tentang eksistensi dan tugas yang diembang para rasul sebagai pembawa risalah, maka lebih tepat jika jawabannya ditemukan melalui penuturan Alquran tentang risālah tersebut. Alquran banyak mengungkapkan makna risalah, baik dilihat dari sisi tekstual maupun dari sisi kontekstual yang dapat memberikan makna yang variatif. Oleh karena ini, tulisan ini akan membahas bagaimana pandangan Alquran tentang risālah.

\section{PENGERTIAN RISĀLAH}

Secara etimilogis, al-risālah berasal dari kata رسل terdiri dari , , dan J. Menurut para languist, struktur ini menunjukkan makna الامتداد dan yang berarti bangkit, hidup, dan

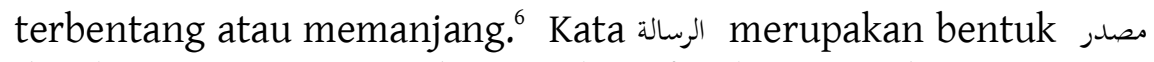
dari kata yang tersusun dari tiga huruf, yakni , س ل رل Jan J.

Dalam kamus istilah fikih disebutkan bahwa risālah mengandung beberapa makna, seperti: surat, keterangan, atau perintah yang dibawa oleh Nabi Muhammad saw. sebagai bukti kerasulannya. ${ }^{7}$ Dapat pula berarti surat yang dikirim atau karya tulis. $^{8}$

Kata الرسالة sering pula diartikan dalam kehidupan seharihari dengan surat atau pesan tertulis. Hal itu dapat saja diartikan

${ }^{6}$ Abū al-Husain Ahmad ibn Fāris ibn Zakariya, Mu'jam Maqāȳis alLughah, Juz II (t.tp: Dār al-Fikr, 1979), h. 392; Lihat pula al-Raghīb al-Asfahānī, Mu'jam Mufradāt al-Fāz al-Qur'ān (Bairut: Dār al-Fikr, t.th.), h. 200-201.

${ }^{7}$ M. Abd. Mujieb, dkk. Kamus Istilah Fiqhi (Cet. I; Jakarta: Pustaka Firdaus, 1994), h. 297.

${ }^{8}$ Tim Penyusun Pusat Pembinaan dan Pengembangan Bahasa, Kamus Besar Bahasa Indonesia, edisi II (Cet. IV; Jakarta: Balai Pustaka, 1995), h. 843. 
demikian, karena wahyu sebagai risalah yang datang dari Allah yang berisi keterangan dan pesan-pesan tertulis yang dikirim oleh Allah kepada manusia melalui malaikat Jibril kepada rasulNya. Orang yang diutus atau diberi amanat untuk menyampaikan

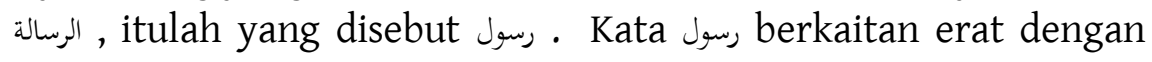

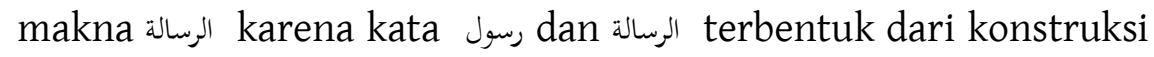

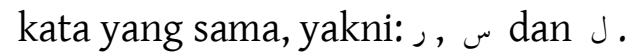

Apabila kata رسول disandarkan pada kata الرسالة , maka berarti segala yang diperintahkan Allah swt. untuk disampaikan atau mengajak manusia pada apa yang telah diwahyukan Allah swt. kepadanya (rasul). ${ }^{9}$ Dapat pula dikatakan bahwa الرسالة adalah ajaran-ajaran Allah swt. yang disampaikan melalui perantaraan seorang atau beberapa orang rasul untuk mengatur kehidupan manusia dalam hubungannya dengan Allah swt., sesama manusia, dan makhluk lingkungannya. ${ }^{10}$

\section{SUBTANSI RISĀLAH MENURUT ALQURAN}

Kata الرسالة dapat ditemukan dalam Alquran sebanyak 10 kali dan termuat dalam 5 surat, yaitu: Q.S. al-Māidah (5): 67; Q.S. alAn'ām (6): 124; Q.S. al-A'rāf (7): 62, 68,79, 93 dan 144; Q.S. al-Ahzāb (33): 39; Q.S. al-Jin (72): 23 dan $28 .{ }^{11}$ Jika kelima surat dilihat berdasarkan kronologis turunnya, surat tersebut dapat disusun sebagai berikut: Q.S. al-A'rāf (7): 39; Q.S. al-Jin (72): 40; Q.S. alAn'ām (6):55); Q.S. al-Aḥzāb (33): 90; dan Q.S. al-Mā’idah (5):112). Untuk memperoleh penjelasan tentang konsep الرسالة sesuai yang diharapkan maka penulis mengambil Q.S. al-A'rāf (7):62 yang merupakan surat yang pertama yang berkaitan dengan risālah sebagai titik kajian dalam tulisan ini. Ayat yang dimaksud adalah:

\footnotetext{
${ }^{10}$ Dewan Redaksi Ensiklopedi Islam, Ensiklopedi Islam, Jilid 4 (Cet. III; Jakarta: Ichtiar Baru Van Hoeve, 1994), h. 172-173

${ }^{11}$ Muḥammad Fua'd 'Abd al-Bāqī, al-Mu'jam al-Mufahras li al-Fāz alQur'ān al-Karīm (t.tp.: Dār al-Fikr, t.th.), h. 319
} 1972), 344

9 Ibrāhīm Ānis, et. al., al-Mu'jam al-Wasịt, Juz I (Cet. II; Qāhirah: t.tp., 


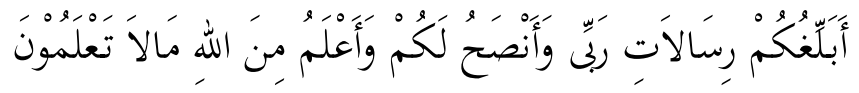

Aku sampaikan kepadamu amanat-amanat Tuhanku dan aku memberi nasehat kepadamu. dan aku mengetahui dari Allah apa yang tidak kamu ketahui, (Q.S. al-A'rāf [7/39]: 62).

Dari ayat di atas dapat dipahami bahwa risālah pada prinsipnya merupakan pesan-pesan Tuhan yang dibawa oleh manusia pilihan Allah yang bertugas menyampaikan dan mengajari umatnya atas rekomendasi langsung dari Allah.

Kejahatan dan kebaikan merupakan sebuah keniscayaan akan eksistensinya. Dengan demikian, manusia telah diilhami fujūr (potensi keburukan) dan taqwā (potensi kebaikan) yang kemudian potensi itu berkembang. Dalam perkembangannya, manusia membutuhkan tuntunan ke jalan yang benar untuk mengembangkan potensi yang baik itu. Itulah salah satu faktor terpenting sehingga Allah memilih rasul untuk mengajari manusia ajaran atau pesan-pesan. Inilah yang kemudian disebut risālah atau wahyu.

Alquran dalam mengungkap risālah sangat rasional, karena etika Alquran didasarkan pada prinsip logis bahwa segala sesuatu yang membahayakan keselamatan umat manusia adalah immoral. ${ }^{12}$ Risālah atau wahyu merupakan pancaran, malaikat adalah kekuatan yang memancarkan dan diterima oleh nabi dan yang turun kepada mereka merupakan pancaran yang bersambung dan terperinci dan menjadi kekhususan bagi para

\footnotetext{
${ }^{12}$ Alquran memperhatikan persoalan-persoalan fundamental dan sekaligus memberi jawaban dan menawarkan solusi. Problem yang paling fundamental sepanjang sejarah perjalanan manusia adalah pengingkaran manusia terhadap Tuhan. Atas dasar itulah setiap nabi dan rasul pembawa risālah selalu menyerukan: "Beriman dan bertakwalah kepada Tuhan". Pengingkaran kepada Tuhan adalah bukti yang nyata terhadap adanya yang diingkari (Tuhan). Yang dapat diingkari eksistensinya adalah yang mempunyai eksistensi, karena pengingkaran terhadap eksistensi bagi yang eksis adalah pembenaran.
} 
penerimanya. ${ }^{13}$ Sementara rasul yang menerima risālah itu adalah orang yang menyampaikan apa yang ia peroleh dari pancaran tersebut.

Hal itu dapat dijumpai, misalnya dalam risālah Musa pada Fir'aun, ${ }^{14}$ ketika Allah menyuruh Musa dan saudaranya menemui Fir'aun dan mengatakan kepadanya "Sesungguhnya Kami adalah Rasul Tuhan semesta alam, lepaskanlah Bani Israil (pergi) beserta kami". Ini dapat dipahami bahwa Fir'aun secara tidak langsung harus beriman kepada Tuhan tetapi risālah yang disampaikan kepadanya adalah agar berhenti melakukan penyiksaan dan pembunuhan terhadap orang-orang Israel. Inti dari risalah kepada Fir'aun adalah hanya beriman kepada Tuhan semesta alam. Kendala yang menghambat Fir'aun beriman kepada Tuhan adalah sifat sombong.

Begitu pula pada Q.S. al-Syu'arā' (26): 69-184 adalah kisah tentang Ibrahim. Yang diminta oleh Ibrahim kepada ayah dan kaumnya adalah agar mereka mengakui Tuhan Yang Maha Esa dan menyingkirkan berhala. Belum diajak mereka untuk melaksanakan ibadah seperti rukun Islam yang ada sekarang. Nabi Ibrahim mendakwahkan bahwa moralitas itu penting karena moralitas adalah pilar untuk membangun masyarakat yang berperadaban dan berkehidupan yang layak. Hal ini pula yang menunjukkan bagaimana Alquran menyesuaikan kondisi.

Pada ayat 107-108 dalam surat yang sama, Nuh menyatakan dirinya sebagai rasul yang terpercaya, selanjutnya ia memerintahkan untuk menyembah kepada Allah dan taat kepada Nuh. Secara filosofis, ayat ini sebenarnya menunjukkan sebuah revolusi kemanusiaan yang hakiki, yang memerdekakan manusia dari seluruh bentuk perbudakan.

\footnotetext{
${ }^{13}$ Nurcholis Madjid (Ed.), Khazanah Intelektual Islam (Jakarta: Bulan Bintang, 1984), h. 140-141.

${ }^{14}$ Q.S. al-Syu'arā' (26): 10-68.
} 
Dari kenyataan sejarah, para nabi dan rasul Allah menunjukkan bahwa esensi risālah yang sebenarnya adalah mengajak manusia untuk beriman dan menyembah Tuhan. Atas dasar inilah risālah atau pesan yang dibawa oleh para nabi dan rasul Allah itu disesuaikan dengan kondisi dan fenomena historis kaumnya sehingga tampak pesan para nabi dan rasul Allah kepada kaum itu bervariasi. Akan tetapi, dilihat dari segi akidah dan tauhid, semua risālah mengajak manusia untuk percaya dan menyembah Tuhan dan mentaati rasul.

\section{WUJUD RISĀLAH DALAM ALQURAN}

Kata رسَالات رسالة merupakan jamak dari kata diterjemahkan dengan makna amanat. Kemudian kata رسالة dihubungkan dengan kata بلغ yang berarti menyampaikan. Dengan demikian, dapat dipahami bahwa رسآلت, yang berbentuk jamak pada ayat di atas merupakan amanat yang mesti disampaikan Rasul-Nya. Risālah dalam bentuk jamak (risālāt) mengandung kesan bahwa tuntunan Ilahi itu banyak bentuknya. Dapat juga berarti menempuh proses yang sangat panjang dan berkesinambungan. ${ }^{15}$ Selain itu, kata رسآلات, disandarkan kepada kata رَبَّى sehingga mengandung makna bahwa penyampaian itu benar-benar dari Allah bukan dari manusia (rasul), rasul hanya menyampaikan dan memberi nasihat.

Pada ayat 68 dalam surat yang sama di atas (Q.S. al-A'rāf [7]) diawali bunyi ayat yang sama dengan ayat 62 , hanya lanjutan dan subjek ayat yang berbeda.

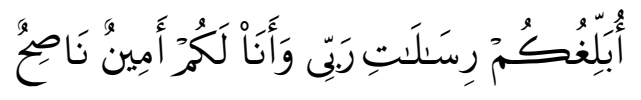

Aku menyampaikan amanat-amanat Tuhanku kepadamu dan aku hanyalah pemberi nasehat yang terpercaya bagimu. (Q.S. al-A'raf [7]:68).

${ }^{15}$ M. Quraish Shihab, Tafsir al-Misbah: Pesan, Kesan, dan Keserasian alQur'an, Jilid V (Cet. V; Jakarta: Lentera Hati, 2006), h. 134. 
Ayat 62 berkaitan dengan Nabi Nuh as. yang menyatakan

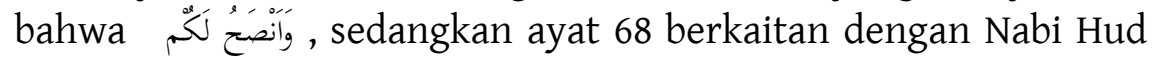

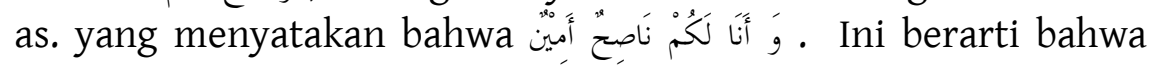
Nabi Nuh as. terus-menerus menyampaikan nasehatnya betapapun kaumnya menolak dan membencinya. Sementara itu, Nabi Hud as. menyakinkan umatnya bahwa ia pembawa nasehat kebenaran. Kata كَ jada kedua ayat di atas menunjukkan bahwa yang rasul lakukan adalah semata-mata untuk mereka (kaumnya), bukan menuntut keuntungan dari mereka. ${ }^{16}$

Bunyi ayat seperti terdapat pada ayat 62 dan 68, juga ditemukan pada ayat 79 dan 93 dalam surah yang sama.

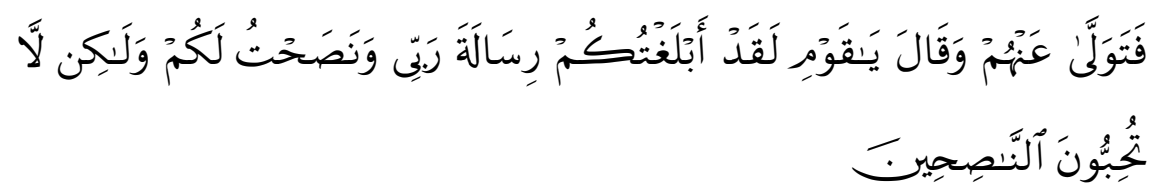

Maka Saleh meninggalkan mereka seraya berkata: "Hai kaumku Sesungguhnya aku telah menyampaikan kepadamu amanat Tuhanku, dan aku telah memberi nasehat kepadamu, tetapi kamu tidak menyukai orang-orang yang memberi nasehat. (Q.S. al-A'rāf [7]: 79).

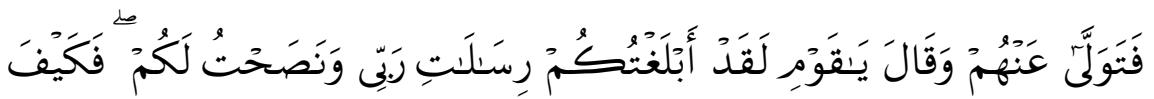

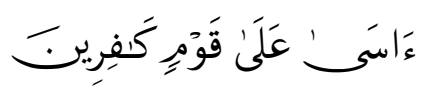

Maka Syu'aib meninggalkan mereka seraya berkata: "Hai kaumku, Sesungguhnya aku telah menyampaikan kepadamu amanat-amanat Tuhanku dan aku telah memberi nasehat kepadamu. Maka bagaimana aku akan bersedih hati terhadap orang-orang yang kafir?, (Q.S. al-A'rāf [7]:93).

Dari dua ayat terakhir di atas, kata رسَآلآ disandarkan kepada kata رَِّّ seperti dua ayat sebelumnya mengandung makna penegasan bahwa itu bukan kecerdasan dan kelihaian rasul-Nya

${ }^{16}$ Ibid; Lihat pula H.G. Sarwar, Filsafat al-Qur'an, terj. Zaenal Muhtadin Mursyid (Cet. IV; Jakarta: RajaGrafindo Persada, 1994), h. 188. 
membuat hal itu, tetapi itu akibat dari kebinasaannya, maka kaum Nabi Saleh as. ditimpakan bencana. Demikian pula Nabi Syu'aib as., kaumnya tidak mengindahkan nasihat atau risālah yang disampaikan, maka ayat ini menggunakan kata yang sama فتَّكَ 17 yang berarti "maka ia berpaling" meninggalkan kaumnya

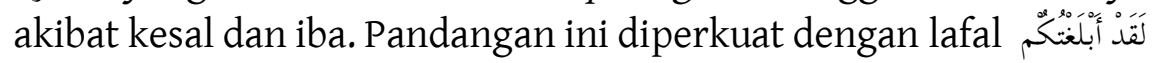
bentuk lampau yang menunjukkan kesungguhan bahwa kedua nabi tersebut pernah menyampaikan risalah secara maksimal, namun kaumnya tidak mengindahkannya.

Ayat-ayat yang disebutkan di atas selalu dikaitkan dengan tugas para nabi dan rasul Allah. Itu berarti bahwa para rasul sangat dekat dengan istilah risālah dalam konteks sebagai tugas yang diembannya. Hal itu dapat dilihat dalam Q.S. al-Māidah (5): 67 berikut ini:

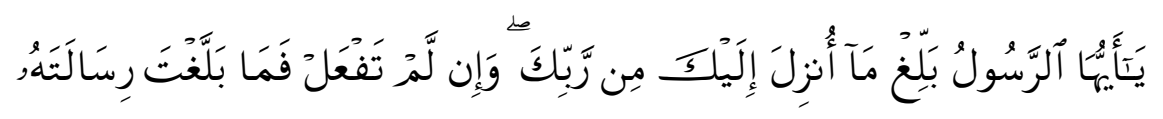

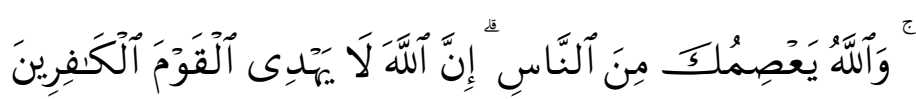

Hai rasul, sampaikanlah apa yang diturunkan kepadamu dari Tuhanmu. dan jika tidak kamu kerjakan (apa yang diperintahkan itu, berarti) kamu tidak menyampaikan amanat-Nya. Allah memelihara kamu dari (gangguan) manusia. Sesungguhnya Allah tidak memberi petunjuk kepada orang-orang yang kafir.

Pada ayat lain Allah berfirman:

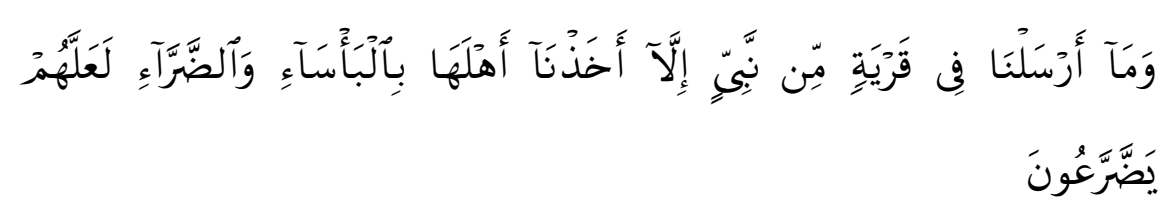

Kami tidaklah mengutus seseorang nabipun kepada sesuatu negeri, (lalu penduduknya mendustakan Nabi itu), melainkan Kami timpakan kepada

${ }^{17}$ M. Quraish Shihab, Tafsir al-Misbah ..., h. 158; lihat pula H. G. Sarwar, Filsafat..., h. 190 
penduduknya kesempitan dan penderitaan supaya mereka tunduk dengan merendahkan diri (Q.S. al-A'rāf [7]:94).

Dari kedua ayat di atas dapat dikemukakan bahwa rasul dan nabi memiliki tugas yang sama yaitu untuk menyampaikan amanat dari Allah swt. Hal itu dapat dimaklumi karena proses pengangkatan seorang rasul Allah itu didahului dengan penunjukannya sebagai nabi yang telah mendapat nubuwah. Dengan demikian, pandangan yang mengatakan bahwa nabi tidak memiliki kewajiban menyampaikan risālah,' perlu ditinjau ulang karena terbukti bahwa penduduk suatu negeri yang tidak mau mengikuti risālah yang disampaikan oleh seorang nabi akan ditimpakan kesulitan dan penderitaan.

Ayat yang menceritakan kisah tentang Syu'aib (Q.S. al-A'rāf [7/39]:93-94) sebagai seorang nabi ternyata juga mendapat wahyu atau risālah untuk disampaikan kepada kaumnya karena kaumnya adalah kaum yang berpenghidupan sebagai saudagar yang menjalankan penipuan dan praktek riba. Syu'aib membawa pesan kepada kaumnya agar menimbang dengan penuh dan jangan disusutkan, beri bobot disertai dengan keadilan yang tulus, jangan merugikan orang dan jangan berbuat kerusakan di muka bumi. Selain itu ia berpesan pula agar kaumnya menyembah Tuhan yang menciptakan manusia dan umat-umat terdahulu. ${ }^{18}$

Pesan di atas ternyata mengandung pesan atau risālah yang esensinya adalah perintah untuk beriman dan menyembah Allah dalam pengertian yang luas. Setiap nabi dan rasul memiliki kesamaan formulasi kalimat dalam menyampaikan risālah, yaitu: "Sembahlah Tuhan dan Patuhilah Aku". Hanya saja, perintah tersebut selalu dikaitkan dengan zamannya.

\section{FUNGSI $A L-R I S \bar{A} L A H$ DALAM ALQURAN}

Fungsi misi rasul Allah tak dapat dipisahkan dengan tujuan risālah, sebab risālah dan rasul ibarat barang yang dibawa dan

${ }^{18}$ H. G. Sarwar, Filsafat ..., h. 190-191 
pembawanya. Nilai dan kedudukan para rasul as. di antara bangsa-bangsa adalah sebagaimana pentingnya akal pada diri tiap manusia. Para rasul membimbing akal untuk mengenal Allah dan sifat-sifat-Nya yang wajib diketahui oleh manusia. ${ }^{19}$ Berbeda halnya dengan orientalis yang menempatkan Muhammad saw. tidak lebih dari sekedar fenomena sejarah. ${ }^{20}$ Pandangan ini kemudian "menghilangkan" status Muhammad saw. sebagai nabi dan rasul Allah. Para orientalis tidak membedakan Muhammad saw. sebagai fenomena sejarah dan Muhammad saw. sebagai objek keimanan penganutnya (umat Islam).

Tampaknya ada perbedaan secara konsepsional dan esensial antara ajaran Islam (Alquran) dan Perjanjian Baru dalam Injil. Akan tetapi, dalam Perjanjian Lama terdapat pengakuan bahwa nabi menerima wahyu dari Tuhan. ${ }^{21}$ Rasul dalam konsep Alquran menyatukan kalimat untuk menyembah satu Tuhan, yaitu Allah yang tidak bisa dibagi-bagi. Rasul juga membawa risalah yang menyatakan kepada manusia apa yang mereka pertengkarkan akibat pikiran dan keinginan mereka.

Selain itu hal tersebut di atas, risālah yang dibawa oleh para rasul mensyariatkan ajaran moral yang utama. Para rasul mengajak manusia untuk memalingkan hawa nafsu dari kelezatan dunia yang fana untuk mencapai idea (cita-cita) yang tinggi. Dalam kaitan ini pula, rasul memberitakan kepada manusia tentang yang gaib yang diizinkan Allah untuk mereka ketahui. Hal ini senada dengan yang dikemukakan oleh Yūsuf al-Qarḍāwī bahwa fungsi risālah sebenarnya sama dengan fungsi rasul sebagai pembawa risālah. Ia mendasarkan pendapatnya pada ayat

\footnotetext{
${ }^{19}$ Syekh Muhammad Abduh, Risalah Tauhid, alihbahasa Firdaus A.N (Cet. X; Jakarta: Bulan Bintang, 1996), h. 97.

${ }^{20} J a m e s$ E. Royster, "The Study of Muhammad: A Survey of Approaches from the Perspective of History and Phenomenology of Religion," The Muslim World, No. 62, 1972, h. 67.

${ }^{21}$ M. Nasir Mahmud, Orientalisme: al-Qur'an di Mata Barat, Sebuah Studi Evaluasi (Semarang: Dina Utama, 1997), h. 206.
} 
44 dan 64 surat al-Naḥl. ${ }^{22}$ Hanya saja, jika diperhatikan ayat ini ternyata ditujukan kepada Nabi Muhammad saw. sebagai pemberi penjelasan.

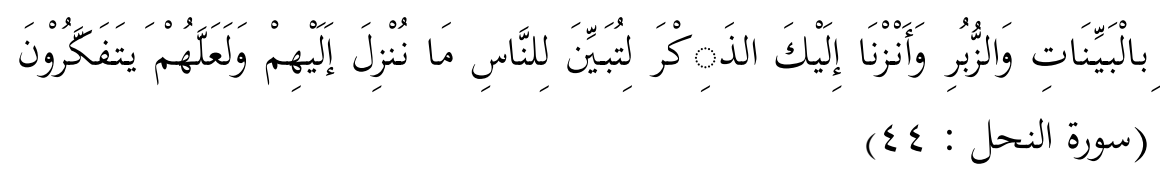

Keterangan-keterangan (mukjizat) dan kitab-kitab. dan Kami turunkan kepadamu al-Qur'an, agar kamu menerangkan pada umat manusia apa yang telah diturunkan kepada mereka dan supaya mereka memikirkan. (Q.S. al-Nahl [16]: 44).

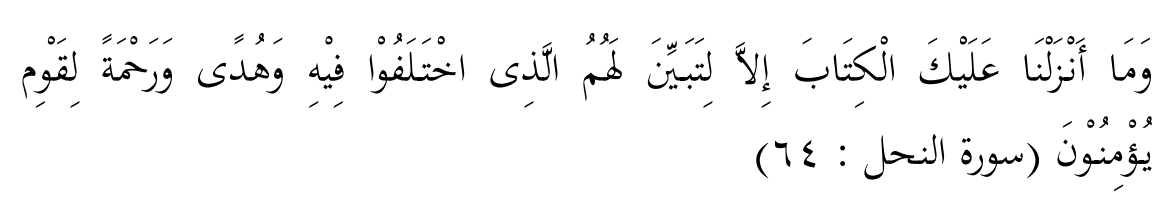

Dan Kami tidak menurunkan kepadamu al-Kitab (al-Qur'an) ini, melainkan agar kamu dapat menjelaskan kepada mereka apa yang mereka perselisihkan itu dan menjadi petunjuk dan rahmat bagi kaum yang beriman. (Q.S. al-Nahl [16]: 64).

Meskipun ayat ini kelihatan secara khusus menunjuk tugas dan fungsi Nabi Muhammad saw. sebagai penjelas atas risālah atau Alquran dari Allah, para rasul dan nabi Allah sebelumnya juga mendapat tugas yang "sama" dalam menyelesaikan perkara yang diperselisihkan manusia atau umatnya pada zamannya. Selain itu nabi juga mengajak manusia untuk bertauhid dan menyembah kepada Tuhan Yang Maha Esa. Bahkan, Sa'id Nursi seorang pemikir terkemuka dari Turki mengatakan bahwa risālah juga menunjukkan risālah "nubuwah". ${ }^{23}$ Ia meyakini bahwa nabi juga mendapat risālah dari Tuhan. Pendapat tersebut paling tidak mengalami loncatan jauh melampaui makna lafal karena ia

\footnotetext{
${ }^{22}$ Yūsuf al-Qardawī, Śaqāfat al-Dā'iyah (Cet. IV; Bairut: Muassasah alRisālah, 1981), h. 52.

${ }^{23}$ Badi' al-Zamān Sa'id Nursi, Al-Kalimat, terj. Iḥsān Qāsim al-Ṣālihī (Cet.III; Istambul: Syirkah Sozler, 1998), h. 831.
} 
mendasarkan pikirannya pada Q.S. al-Fath (48):28-29 dan Q.S. alA'rāf (7):158.

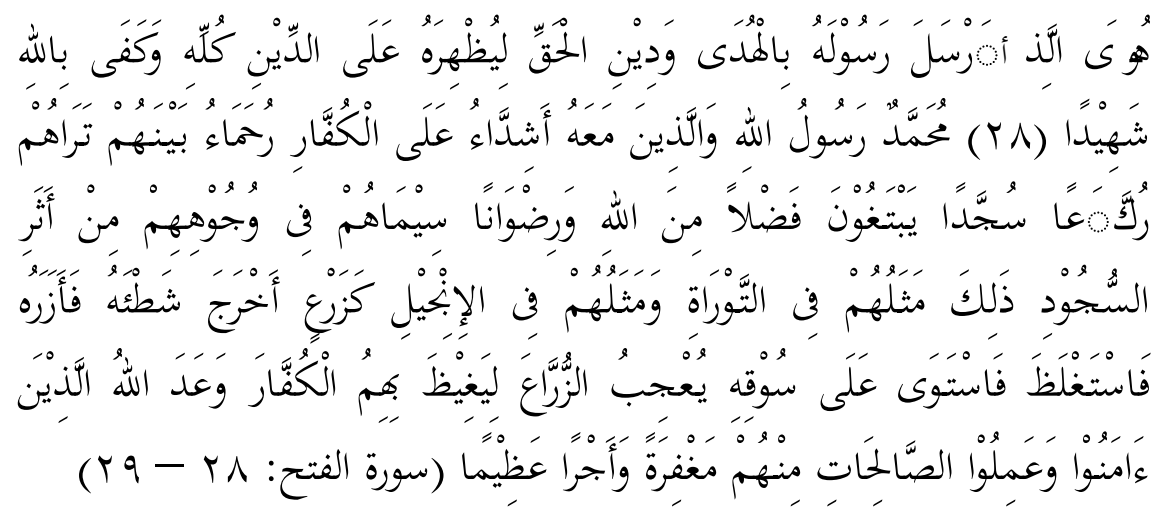

28. Dia-lah yang mengutus Rasul-Nya dengan membawa petunjuk dan agama yang hak agar dimenangkan-Nya terhadap semua agama. dan cukuplah Allah sebagai saksi.

29. Muhammad itu adalah utusan Allah dan orang-orang yang bersama dengan Dia adalah keras terhadap orang-orang kafir, tetapi berkasih sayang sesama mereka. kamu lihat mereka ruku' dan sujud mencari karunia Allah dan keri«aan-Nya, tanda-tanda mereka tampak pada muka mereka dari bekas sujud. Demikianlah sifat-sifat mereka dalam Taurat dan sifat-sifat mereka dalam Injil, yaitu seperti tanaman yang mengeluarkan tunasnya, maka tunas itu menjadikan tanaman itu kuat lalu menjadi besarlah. dia dan tegak lurus di atas pokoknya; tanaman itu menyenangkan hati penanam-penanamnya karena Allah hendak menjengkelkan hati orang-orang kafir (dengan kekuatan orang-orang mukmin). Allah menjanjikan kepada orang-orang yang beriman dan mengerjakan amal yang saleh di antara mereka ampunan dan pahala yang besar. (Q.S. al-Fath [48]: 28-29).

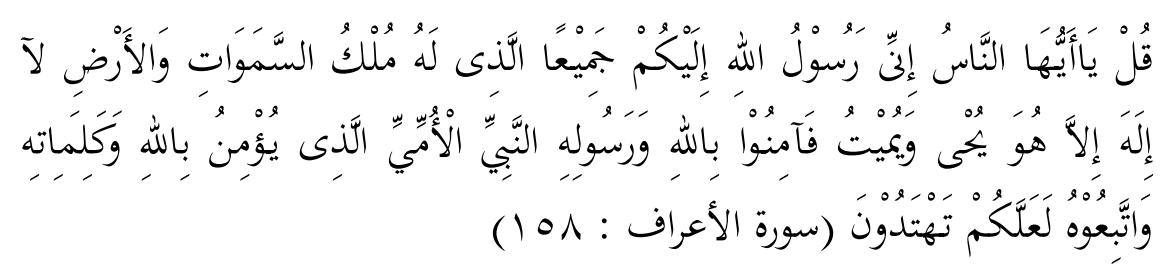

Katakanlah: "Hai manusia Sesungguhnya aku adalah utusan Allah kepadamu semua, yaitu Allah yang mempunyai kerajaan langit dan bumi; tidak ada Tuhan (yang berhak disembah) selain Dia, yang 
menghidupkan dan mematikan, Maka berimanlah kamu kepada Allah dan Rasul-Nya, Nabi yang ummi yang beriman kepada Allah dan kepada kalimat-kalimat-Nya (kitab-kitab-Nya) dan ikutilah dia, supaya kamu mendapat petunjuk. (Q.S. al-'Arāf [7]: 158).

Ayat di atas secara tegas menyebut kata "rasul" yang diutus untuk menyampaikan risālah Allah swt. kepada manusia. Itu berarti risālah itu mengandung makna sebagai tugas kerasulan yang bertujuan menjadi petunjuk dan pedoman hidup untuk meraih kebahagiaan dunia dan akhirat. Walaupun demikian, pandangan Sa'id Nursi tersebut dapat pula diterima jika yang dimaksud bahwa risālah adalah isyarat nubuwah karena sebagian nabi juga adalah rasul tetapi tidak sebaliknya. Jika diperhatikan ayat-ayat yang menunjuk pada realitas sejarah para nabi yang diutus untuk memberi peringatakan kepada kaumnya yang melampaui batas atau melanggar aturan. Risālah dan para nabi dan rasul Allah diturunkan sesuai dengan kondisi masyarakat pada zamannya. Hanya saja, masih perlu dipertimbangkan karena sebagian ulama mendefinisikan nabi dengan satu kata kunci bahwa nabi tidak wajib menyampaikan wahyu yang diterimanya kepada umat manusia. Penulis berpandangan bahwa yang dimaksud dengan wahyu terakhir ini adalah kitab suci sebagai kitab pedoman hidup. sedangkan yang dimaksud risālah dalam Alquran adalah seluruh amanat dan tugas para nabi dan rasul Allah yang berfungsi untuk mengatur kehidupan manusia dalam hubungannya dengan Allah, sesama manusia, dan lingkungannya.

\section{PENUTUP}

Risālah yang dimaksud dalam Alquran adalah ajaran Allah swt. yang disampaikan-Nya dengan perantaraan seseorang atau beberapa orang rasul pilihan Allah untuk mengatur kehidupan manusia dalam hubungannya dengan Tuhan, sesamanya, dan lingkungannya. Dalam Alquran, risālah terkadang dihubungkan dengan "nabi" sehingga risālah dalam arti umum adalah seluruh amanat dan tugas para nabi dan rasul Allah untuk disampaikan 
dan diajarkan kepada kaumnya untuk mencapai kebahagiaan dunia dan akhirat.

Wujud risālah adalah pesan-pesan Tuhan yang dibawa oleh manusia pilihan Allah, sehingga eksistensi risālah tidak dapat dipisahkan dengan kehadiran para rasul Allah di tengah-tengah umat manusia pada setiap zaman. Para rasul Allah adalah pembawa risālah untuk memberi jawaban atas persoalan yang dihadapi. Risālah ini merupakan isyarat dan bukti kenabian dan kerasulan.

Fungsi diturunkannya risalah oleh Allah adalah untuk menuntun jalan hidup manusia. Gaya bahasa Alquran ketika menyebut risālah bervariasi karena hal ini dilatarbelakangi oleh permasalahan yang dihadapi umat dari setiap zaman. Selain itu, risalah juga berfungsi untuk memberitakan kepada manusia tentang hal-hal yang gaib, mengajak manusia untuk bertauhid dan menyembah hanya kepada Tuhan. Kebutuhan manusia kepada risālah dan rasul adalah untuk melengkapi akal yang sangat terbatas.

Allah swt. Maha Pengasih dan Maha Penyayang terhadap hamba-Nya. Oleh karena itu, Ia membekali manusia dengan akal dan mengutus Rasul-Nya untuk mengajarkan manusia tentang hal-hal gaib yang wajib dipercayainya dan menentukan batas antara yang baik dan buruk.

\section{DAFTAR PUSTAKA}

Abduh, Muhammad, Risalah al-Tauhid, alihbahasa Firdaus A.N., Cet. X; Jakarta: Bulan Bintang, 1996.

Abū al-Husain Aḥmad ibn Fāris ibn Zakariya, Mu'jam Maqāyīs al-Lugat Juz II. t.tp: Dar al-Fikr, 1979.

Ānis, Ibrāhīm, et. al., al-Mu'jam al-Wasịt, Juz I. Cet. II; Qahirah: t.tp., 1972. 
Bāqī, Muhammad Fu'ad 'Abd al-, al-Mu'jam al-Mufahras li al-Fāz alQur'ān al-Karìm (t.tp.: Dar al-Fikr, t.th.

Dewan Redaksi Ensiklopedi Islam, Ensiklopedi Islam, Jilid 4. Cet. III; Jakarta: Ichtiar Baru Van Hoeve, 1994.

Madjid, Nurcholis (Ed.), Khazanah Intelektual Islam. Jakarta: Bulan Bintang, 1984.

Mahmud, M. Nasir, Orientalisme: al-Qur'an di Mata Barat, Sebuah Studi Evaluasi. Semarang: Dina Utama, 1997.

Mujieb, M. Abd., dkk. Kamus Istilah Fiqhi. Cet. I; Jakarta: Pustaka Firdaus, 1994.

Mūsā, Yūsuf. Islam: Suatu Kajian Komprehensif, terj. Malik Madaniy dan Hamim. Cet. I; Jakarta: Rajawali, 1988.

Raghīb al-Asfahānī, al-. Mu'jam Mufradāt al-Fāz al-Qur'ān. Bairut: Dar al-Fikr, t.th.

Nasution, Harun, Teologi Islam: Aliran-aliran Sejarah, Analisa Perbandingan. Cet. II; Jakarta: UI Press, t.th.

Nursi, Badi' al-Zamān Sa'id, Al-Kalimat, terj. Iḥsān Qāsim al-Ṣālihī III; Istambul: Syirkah Sozler, 1998.

Qarḍāwī, Yūsuf al- Śaqāfat al-Dā’iyah. Cet. IV; Baerut: Muassasat alRisālah, 1981.

Royster, James E., "The Study of Muhammad: A Survey of Approaches from The Perspective of History and Phenomenology of Religion," The Muslim World, N0. 62, 1972.

Sarwar, H.G., Filsafat al-Qur'an, terj. Zaenal Muhtadin Mursyid, Cet. IV; Jakarta: RajaGrafindo Persada, 1994.

Shihab, M. Quraish, Tafsir al-Misbah: Pesan, Kesan, dan Keserasian alQur'an, Jilid V. Cet. V; Jakarta: Lentera Hati, 2006.

Shihab, M. Quraish, Wawasan al-Qur'an: Tafsir Maudhu'i atas Pelbagai Persoalan Umat. Cet. II; Bandung: Mizan, 1996.

Tim Penyusun Pusat Pembinaan dan Pengembangan Bahasa, Kamus Besar Bahasa Indonesia, Ed. II. Cet. IV; Jakarta: Balai Pustaka, 1995. 